\title{
Profile of presentation of HIV-positive patients to an emergency department in Johannesburg, South Africa
}

\begin{tabular}{|c|c|}
\hline \multicolumn{2}{|c|}{$\begin{array}{l}\text { Authors: } \\
\text { Abdullah E. Laher }{ }^{1} \\
\text { Willem D.F. Venter } \\
\text { Guy A. Richards } \\
\text { Fathima Paruk } \\
\text { Fa }\end{array}$} \\
\hline \multicolumn{2}{|c|}{$\begin{array}{l}\text { Affiliations: } \\
{ }^{1} \text { Department of Emergency } \\
\text { Medicine, Faculty of } \\
\text { Health Sciences, University } \\
\text { of the Witwatersrand, } \\
\text { Johannesburg, South Africa }\end{array}$} \\
\hline \multicolumn{2}{|c|}{$\begin{array}{l}{ }^{2} \text { Ezintsha, Faculty of } \\
\text { Health Sciences, University } \\
\text { of the Witwatersrand, } \\
\text { Johannesburg, South Africa }\end{array}$} \\
\hline \multicolumn{2}{|c|}{$\begin{array}{l}{ }^{3} \text { Department of Critical } \\
\text { Care, Faculty of Health } \\
\text { Sciences, University of } \\
\text { the Witwatersrand, } \\
\text { Johannesburg, South Africa }\end{array}$} \\
\hline \multicolumn{2}{|c|}{$\begin{array}{l}{ }^{4} \text { Department of Critical Care, } \\
\text { University of Pretoria, } \\
\text { Pretoria, South Africa }\end{array}$} \\
\hline \multicolumn{2}{|c|}{$\begin{array}{l}\text { Corresponding author: } \\
\text { Abdullah Laher, } \\
\text { abdullahlaher@msn.com }\end{array}$} \\
\hline \multicolumn{2}{|c|}{$\begin{array}{l}\text { Dates: } \\
\text { Received: } 11 \text { Oct. } 2020 \\
\text { Accepted: } 15 \text { Nov. } 2020 \\
\text { Published: } 29 \text { Jan. } 2021\end{array}$} \\
\hline \multicolumn{2}{|c|}{$\begin{array}{l}\text { How to cite this article: } \\
\text { Laher AE, Venter WDF, } \\
\text { Richards GA, Paruk F. } \\
\text { Profile of presentation of } \\
\text { HIV-positive patients to } \\
\text { an emergency department } \\
\text { in Johannesburg, } \\
\text { South Africa. S Afr J HIV } \\
\text { Med. 2021;22(1), a1177. } \\
\text { https://doi.org/10.4102/ } \\
\text { sajhivmed.v22i1.1177 }\end{array}$} \\
\hline \multicolumn{2}{|l|}{ Read online: } \\
\hline 回的回 & $\begin{array}{l}\text { Scan this QR } \\
\text { code with your } \\
\text { smart phone or } \\
\text { mobile device } \\
\text { to read online. }\end{array}$ \\
\hline
\end{tabular}

Background: Despite improved availability and better access to antiretroviral therapy (ART), approximately $36 \%$ of human immunodeficiency virus (HIV)-positive South Africans are still not virally suppressed.

Objective: The aim of this study was to describe the patterns of presentation of HIV-positive patients to a major central hospital emergency department (ED).

Methods: In this prospectively designed study, consecutive HIV-positive patients presenting to the Charlotte Maxeke Johannesburg Academic Hospital (CMJAH) adult ED were enrolled between 07 July 2017 and 18 October 2018.

Results: A total of 1224 participants were enrolled. Human immunodeficiency virus was newly diagnosed in $212(17.3 \%)$ patients, 761 (75.2\%) were on ART, 245 (32.2\%) reported ART non-adherence, 276 (22.5\%) had bacterial pneumonia, 244 (19.9\%) had tuberculosis (TB), $86(7.0 \%)$ had gastroenteritis, $205(16.7 \%)$ required intensive care unit admission, $381(31.1 \%)$ were admitted for $\geq 7$ days and $166(13.6 \%)$ died. With regard to laboratory parameters, $\mathrm{CD}_{4}$ cell count was $<100$ cell $/ \mathrm{mm}^{3}$ in $527(47.6 \%)$ patients, the viral load (VL) was $>1000$ copies $/ \mathrm{mL}$ in 619 (59.0\%), haemoglobin was < $11 \mathrm{~g} / \mathrm{dL}$ in 636 (56.3\%), creatinine was > $120 \mathrm{\mu mol} / \mathrm{L}$ in $294(29.3 \%)$, lactate was $>2 \mathrm{mmol} / \mathrm{L}$ in $470(42.0 \%)$ and albumin was < $35 \mathrm{~g} / \mathrm{L}$ in $633(60.8 \%)$.

Conclusion: Human immunodeficiency virus-positive patients presenting to the CMJAH ED demonstrated a high prevalence of opportunistic infections, required a prolonged hospital stay and had high mortality rates. There is a need to improve the quality of ART services and accessibility to care.

Keywords: HIV; emergency department; ART non-adherence; $\mathrm{CD}_{4}$ cell count; HIV viral load; opportunistic infections; hospital admission; mortality.

\section{Introduction}

Human immunodeficiency virus (HIV) infection is an epidemic, which has affected approximately 38 million people worldwide. In 2019, 1.7 million new infections and 690000 HIV-related deaths were recorded. ${ }^{1}$ Two-thirds of the global population of persons living with HIV (PLWH) are in sub-Saharan Africa (SSA). South Africa (SA) contributes approximately 7.5 million to the global number, that is, more than twice that of any other country worldwide. ${ }^{2}$

The availability of antiretroviral therapy (ART) globally has reduced HIV-associated morbidity and mortality rates., Indeed, the life expectancy of PLWH in some regions is now comparable to that of the general population. ${ }^{4,5}$ Although there has been a significant increase in the global number of PLWH on ART in recent years, ${ }^{6}$ the burden of HIV-related illness is still substantial, ${ }^{7}$ especially amongst those who are newly diagnosed, ART-naive and those who were recently initiated on ART. ${ }^{8}$ Other factors contributing to poor HIV-related outcomes include non-adherence to ART, treatment resistance and severe immune deficiency (low $\mathrm{CD}_{4}$ cell counts) at the time of presentation. ${ }^{9}$ Furthermore, loss to follow-up (LTFU) remains a problem despite growth in the numbers starting on ART. ${ }^{4,10}$

Emergency departments (EDs) are frequently the first 'port-of-call' for PLWH who experience an acute deterioration in health. Despite free access to ART in SA's public health system, ${ }^{11}$ recent 
data confirm that approximately $30 \%$ of eligible persons are not yet on ART, and of those on ART, 36\% are not virally suppressed. ${ }^{1}$ Although these figures have improved since the inception of the ART roll-out in 2004,12 admission with acute HIV-related illness is still high. These figures fall short of the 2020/30 Joint United Nations Programme on HIV and AIDS (UNAIDS) 90-90-90 targets..$^{13}$ The country's healthcare service and in particular it's EDs depict an early barometer of progress in achieving these goals.

In this study, we describe the profile of presentation of acutely ill PLWH to the ED of a large tertiary hospital. We also describe demographic characteristics, HIV-related history, vital signs, routine laboratory parameters, presenting diagnosis, patient disposition and outcomes.

\section{Methods}

This study was conducted in the adult medical-ED of the Charlotte Maxeke Johannesburg Academic Hospital (CMJAH), a 1088-bed tertiary-level academic hospital affiliated to the University of the Witwatersrand. The adult medical ED manages all non-trauma patients who, on arrival, are triaged as 'emergent' (red), 'very urgent' (orange), 'urgent' (yellow) and 'routine' (green) based on specific criteria as defined by the SA Triage Scale. ${ }^{14}$ In general, patients who are triaged as 'routine' (green) are referred to a lower-level facility for further management. In addition, patients not residing within the drainage area of the $\mathrm{CMJAH}$, and who are transportation stable, are referred to an appropriate facility closer to the patient's residence.

Before the commencement of data collection, informal training pertaining to the methodology and principles of data collection from medical charts was undertaken by the primary investigator. Furthermore, all doctors employed in the ED were briefed regarding the aims, objectives and design of the study. Doctors were thereafter requested to inform the primary investigator of all HIV-positive patients managed in the ED. Written informed consent for study participation was obtained by the primary investigator or the doctor on shift. If participants were unable to grant consent (e.g. decreased level of consciousness), consent was obtained from the next of kin/legal guardian and later reobtained from the participant after his or her mental condition had improved. Human immunodeficiency virusnegative patients, HIV-unknown patients not consenting to HIV testing and patients not consenting to participate in the study were excluded from the study. Emergency department registers were also reviewed daily in an effort to identify potential participants who were missed by the ED doctors.

The four-question AIDS Clinical Trials Group Adherence Questionnaire (ACTG-AQ) was used in order to determine non-adherence to ART. ${ }^{15}$ The questionnaire was administered to all participants prescribed ART at any time in the past.
Data were extracted from the patient's hospital records by the primary investigator and entered into an anonymised and standardised data collection form. Additional information relevant to the study but not found in the patient's hospital records was directly obtained from the participant, the participant's laboratory records or the participant's next of kin/legal guardian where applicable. Only where the next of kin/legal guardian indicated that they were aware of the participant's HIV status, they were questioned regarding relevant HIV-history such as treatment adherence. Data from hospital records were recorded daily for the entire duration of hospital stay until data collection was completed. Inter-rater reliability was assessed by an independent researcher experienced in the methods of data collection and blinded to the study aims and objectives. Data extracted from a random sample of 43 medical charts were compared with those extracted by the primary investigator.

Data relevant to this study included demographic details, HIV status, prior ART history including non-adherence, vital signs including the Glasgow Coma Scale (GCS) score, respiratory rate, systolic blood pressure, oxygen saturation, heart rate and temperature, baseline laboratory findings at the time of the current presentation including $\mathrm{CD}_{4}$ cell count, HIV viral load (VL), haemoglobin, white cell count, platelet count, urea, creatinine, albumin, lactate, C-reactive protein (CRP) and alanine transaminase (ALT), presenting diagnosis, number of organ systems affected at presentation, disposition from the ED, length of hospital stay and in-hospital mortality. The vital signs data were used to calculate the quick Sequential Organ Failure Assessment (qSOFA) score and the National Early Warning Score 2 (NEWS-2). Both qSOFA and NEWS-2 are standardised scoring tools that characterise acute illness severity, with higher scores indicating greater severity of illness and a higher risk for worse outcomes. ${ }^{16,17}$ The various presenting diagnoses were either microbiologically or histologically confirmed or were deemed as the most likely diagnosis based on clinical assessment, special investigations and after discussion with relevant sub-speciality clinicians. Data were thereafter exported to Microsoft ${ }^{\circledR}$ Excel $^{\circledR}$ (Microsoft 365, Version 16.0.13029.20232) and analysed and described using either the median and standard deviation or frequency and percentages.

\section{Ethical consideration}

Data collection commenced once ethical approval from the University of the Witwatersrand Human Research Ethics Committee (clearance certificate number: M160512) and relevant permissions were obtained. Adult patients ( $\geq 18$ years) known to be living with HIV, including those newly diagnosed, were prospectively enrolled into the study between 07 July 2017 and 18 October 2018. As per the CMJAH ED protocol, besides patients that are already HIV-positive (either self-reported or confirmed on laboratory records of patients that previously attended the facility), all other patients attending the ED are offered HIV-rapid diagnostic testing to determine their HIV status. As per the National Department of Health (NDoH) protocol, and after obtaining 
consent, two different HIV-rapid diagnostic tests were performed where the HIV status was unknown. Blood was initially tested with the Abon HIV 1/2/0 Tri-line Rapid test (Abon Biopharm, Hangzhou, RR China). Reactive samples were subjected to a second confirmatory rapid test, namely, the First Response HIV 1-2.0 card (PMC Medical India Pvt, Ltd, Daman, India). Patients testing positive with both, that is, newly diagnosed as HIV-positive, were also approached for study consent and participation. For patients in whom the first test was positive but the second test was negative, whole blood was drawn and sent to the laboratory for an enzymelinked immunosorbent assay (ELISA) HIV-test. These were only approached for study participation if the confirmatory test was positive.

\section{Results}

During the data collection period, 29416 patients presented to the adult medical ED triage area, of which 11383 were triaged into the ED for further management. The remaining patients were referred to an appropriate facility in accordance with the CMJAH ED triage protocol. A total of 1308 patients were HIV-positive, of which 84 were excluded from the study as informed consent could not be obtained. A total of 1224 participants were included in the final study sample.

Table 1 describes the median (IQR) age of study participants. The median (IQR) age of the entire cohort was 36 (IQR 31-44) years, with the median (IQR) age of men being older than that of women. Other demographic characteristics, new diagnosis with HIV, ART initiation and adherence, vital signs and laboratory findings of study participants are presented in Table 2. Most participants were women $(n=$ $673,55.0 \%)$, black $(n=1174,95.9 \%)$, single $(n=937,76.6 \%)$ and had completed secondary school as the highest level of education $(n=1195,97.6 \%)$. Those who were not South African nationals comprised a fifth $(n=253,20.7 \%)$ of study participants.

Approximately one-sixth of participants $(n=212,17.3 \%)$ were newly diagnosed with HIV at presentation. Of the 1012 participants who were diagnosed with HIV prior to ED presentation, 761 (75.2\%) were on ART. Of these, 245 (32.2\%) were non-adherent as per the ACTG-AQ self-report questionnaire. Respiratory rate was $>20$ breaths $/ \mathrm{min}$ in $434(38.8 \%)$ participants, oxygen saturation was $<90 \%$ in $196(17.5 \%)$, systolic blood pressure was < 90 millimetre of mercury $(\mathrm{mmHg})$ in $116(10.4 \%)$, heart rate was $>110$ beats / $\min$ in $565(50.6 \%)$ and GCS was < 15 in $221(19.2 \%)$ participants.

The overall median $\mathrm{CD}_{4}$ cell count and HIV VL were 112 (IQR, 34-295) cell/cubic millimetre $\left(\mathrm{mm}^{3}\right)$ and 8815

TABLE 1: Description of the median (interquartile range) age of study participants.

\begin{tabular}{lccc}
\hline Variable & Entire cohort & Male & Female \\
\hline Median age (years). (IQR) & $36(31-44)$ & $38(32-45)$ & $35(30-43)$ \\
\hline
\end{tabular}

IQR, interquartile range.
TABLE 2: Description of demographic characteristics, human immunodeficiency virus diagnosis, antiretroviral therapy initiation and adherence, vital signs and laboratory findings of study participants.

\begin{tabular}{|c|c|c|}
\hline Variable & $n$ & $\%$ \\
\hline \multicolumn{3}{|l|}{ Demographic characteristics } \\
\hline \multicolumn{3}{|l|}{ Sex } \\
\hline Female & $673 / 1224$ & 55.0 \\
\hline Male & $551 / 1224$ & 45.0 \\
\hline \multicolumn{3}{|l|}{ Race } \\
\hline Black & $1174 / 1224$ & 95.9 \\
\hline Othert & $50 / 1224$ & 4.1 \\
\hline \multicolumn{3}{|l|}{ Marital status } \\
\hline Single & $937 / 1224$ & 76.6 \\
\hline Married & $287 / 1224$ & 23.4 \\
\hline \multicolumn{3}{|l|}{ Highest level of education } \\
\hline Secondary school & $1195 / 1224$ & 97.6 \\
\hline Primary school & $16 / 1224$ & 1.3 \\
\hline Tertiary education & $13 / 1224$ & 1.1 \\
\hline \multicolumn{3}{|l|}{ Nationality } \\
\hline South African & $971 / 1224$ & 79.3 \\
\hline Non-South African & $253 / 1224$ & 20.7 \\
\hline \multicolumn{3}{|c|}{ HIV diagnosis and ART initiation/adherence } \\
\hline Newly diagnosed with HIV & $212 / 1224$ & 17.3 \\
\hline ART initiated prior to ED presentation $*$ & $761 / 1012$ & 75.2 \\
\hline ART non-adherence & $245 / 761$ & 32.2 \\
\hline \multicolumn{3}{|l|}{ Vital signs } \\
\hline Respiratory rate $>20$ breaths/min & $434 / 1118$ & 38.8 \\
\hline Oxygen saturation < $90 \%$ & 196/1117 & 17.5 \\
\hline Systolic blood pressure $<90 \mathrm{mmHg}$ & $116 / 1117$ & 10.4 \\
\hline Heart rate $>110$ beats $/ \mathrm{min}$ & $565 / 1117$ & 50.6 \\
\hline \multicolumn{3}{|l|}{ Glasgow coma scale } \\
\hline 15 & $929 / 1150$ & 80.8 \\
\hline $12-14$ & $176 / 1150$ & 15.3 \\
\hline 9-11 & $38 / 1150$ & 3.3 \\
\hline$<9$ & $7 / 1150$ & 0.6 \\
\hline \multicolumn{3}{|l|}{ Laboratory findings } \\
\hline $\mathrm{CD}_{4}<100 \mathrm{cell} / \mathrm{mm}^{3}$ & $527 / 1105$ & 47.6 \\
\hline HIV viral load > 1000 copies $/ \mathrm{mL}$ & $619 / 1049$ & 59.0 \\
\hline \multicolumn{3}{|l|}{ Haemoglobin } \\
\hline$>10.9 \mathrm{~g} / \mathrm{dL}$ & $550 / 1129$ & 48.7 \\
\hline $8-10.9 \mathrm{~g} / \mathrm{dL}$ & $366 / 1129$ & 32.4 \\
\hline$<8 \mathrm{~g} / \mathrm{dL}$ & $213 / 1129$ & 18.9 \\
\hline White cell count $<4.0 \times 10^{9} / \mathrm{L}$ & $170 / 1127$ & 15.1 \\
\hline Platelet count $<150 \times 10^{9} / \mathrm{L}$ & $223 / 1121$ & 19.9 \\
\hline Urea $>10 \mathrm{mmol} / \mathrm{L}$ & $277 / 1069$ & 25.9 \\
\hline \multicolumn{3}{|l|}{ Creatinine } \\
\hline$\leq 120 \mu \mathrm{mol} / \mathrm{L}$ & $761 / 1061$ & 71.7 \\
\hline $121-200 \mu \mathrm{mol} / \mathrm{L}$ & $129 / 1061$ & 12.2 \\
\hline$>200 \mu \mathrm{mol} / \mathrm{L}$ & $171 / 1061$ & 16.1 \\
\hline \multicolumn{3}{|l|}{ C-reactive protein } \\
\hline$\leq 10 \mathrm{mg} / \mathrm{L}$ & $164 / 1059$ & 15.5 \\
\hline $11-50 \mathrm{mg} / \mathrm{L}$ & $193 / 1059$ & 18.2 \\
\hline $51-100 \mathrm{mg} / \mathrm{L}$ & $186 / 1059$ & 17.6 \\
\hline$>100 \mathrm{mg} / \mathrm{L}$ & $516 / 1059$ & 48.7 \\
\hline \multicolumn{3}{|l|}{ Lactate } \\
\hline$\leq 2.0 \mathrm{mmol} / \mathrm{L}$ & $648 / 1118$ & 58.0 \\
\hline $2.1-5.0 \mathrm{mmol} / \mathrm{L}$ & $387 / 1118$ & 34.6 \\
\hline$>5.0 \mathrm{mmol} / \mathrm{L}$ & $83 / 1118$ & 7.4 \\
\hline \multicolumn{3}{|l|}{ Albumin } \\
\hline$>34 \mathrm{~g} / \mathrm{L}$ & $408 / 1042$ & 39.1 \\
\hline $25-34 \mathrm{~g} / \mathrm{L}$ & $426 / 1042$ & 40.9 \\
\hline$<25 \mathrm{~g} / \mathrm{L}$ & $208 / 1042$ & 20.0 \\
\hline Alanine transaminase $>100 \mathrm{mmol} / \mathrm{L}$ & $109 / 1029$ & 10.6 \\
\hline
\end{tabular}

Note: The denominator has been included for all variables to account for missing data. ART, antiretroviral therapy; ED, emergency department; HIV, human immunodeficiency virus. $\dagger$, Includes Asian, Caucasian and mixed race.

\$, Percentage calculated amongst participants who were known with HIV prior to ED presentation. 
(37-325 898) copies/millilitre (mL), respectively. Almost half of the study participants $(n=527,47.6 \%)$ had a $\mathrm{CD}_{4}$ cell count of $<100$ cell $/ \mathrm{mm}^{3}$, whilst more than half $(n=619$, $59.0 \%$ ) had a VL of $>1000$ copies $/ \mathrm{mL}$. Amongst participants on ART who reported non-adherence, the HIV VL was $>1000$ copies $/ \mathrm{mL}$ in more than two-thirds of participants $(n=167,68.2 \%)$.

More than half of the participants $(n=579,51.3 \%)$ presented with varying degrees of anaemia (haemoglobin $<11$ grams per decilitre $[\mathrm{g} / \mathrm{dL}])$, whilst creatinine was $>120$ micromole per litre $(\mu \mathrm{mol} / \mathrm{L})$ in $291(23.8 \%)$, CRP was $>10$ millimoles per litre (mmol/L) in $895(74.5 \%)$, lactate was $>2 \mathrm{mmol} / \mathrm{L}$ in $470(42.0 \%)$ and albumin was < $35 \mathrm{~g} / \mathrm{L}$ in $634(60.8 \%)$ participants.

Approximately one-fifth of participants $(n=244,19.9 \%)$ presented with active tuberculosis (TB), of whom $70(28.7 \%)$ had disseminated TB, whilst 143 (58.6\%) had extrapulmonary TB (EPTB). The median $\mathrm{CD}_{4}$ cell count was higher, and the median HIV VL was lower amongst participants with (1) a recurrent episode of TB compared with those with a first episode, (2) TB of a single organ compared with those with disseminated TB and (3) isolated pulmonary TB (PTB) compared with those with EPTB. These and other findings pertaining to TB amongst study participants are presented in Table 3.

Table 4 describes the most frequent presenting diagnoses amongst study participants and the corresponding median (IQR) $\mathrm{CD}_{4}$ cell count and HIV VL. Most participants presented with respiratory system pathology $(n=533$, $43.5 \%)$, followed by pathology involving the genitourinary system ( $n=249,20.3 \%)$, gastrointestinal system $(n=223$, $18.2 \%)$ and central nervous system $(n=145,11.8 \%)$. A total of $838(68.4 \%)$ participants presented with an infectious disease. The most common presenting diagnoses included bacterial pneumonia $(n=276,22.5 \%)$, PTB $(n=171,14.0 \%)$, acute gastroenteritis $(n=56,4.6 \%)$, Pneumocystis jirovecii pneumonia $(n=47,3.8 \%)$, cryptococcal meningitis $(n=38$, $3.1 \%)$, bacterial meningitis $(n=30,2.5 \%)$ and chronic gastroenteritis $(n=30,2.5 \%)$.

Just over one-third presented with pathology affecting one organ system $(n=460,37.6 \%)$ or two organ systems $(n=432$, $35.2 \%)$, whilst the remainder $(n=332,27.2 \%)$ had pathology affecting three or more organ systems.

Table 5 describes the qSOFA and NEWS-2 illness severity scores, patient disposition from the ED, length of hospital stay and in-hospital mortality of study participants. Of note, 196 (17.5\%) had a high qSOFA score ( $\geq 2$ points), 496 $(44.4 \%)$ had a high NEWS-2 score ( $\geq 7$ points), $813(66.5 \%)$ required admission to the general ward and $205(16.7 \%)$ required intensive care unit (ICU) admission. The median length of hospital stay was 4.9 (3.5-8.0) days, with approximately one-third $(n=394,32.2 \%)$ requiring admission for $\geq 7$ days. The overall mortality amongst study participants was $13.6 \%(n=166)$.

\section{Discussion}

To our knowledge, this is the largest single-centre study, describing the presentation of PLWH to an ED in SSA. Noteworthy findings include the large proportion of participants presenting with undiagnosed HIV, ARTtreatment naivety/non-adherence, elevated HIV VL whilst on ART, other deranged laboratory parameters, HIV-related acute illness and in-hospital mortality.

TABLE 3: Description of tuberculosis history and presentation amongst study participants.

\begin{tabular}{|c|c|c|c|c|c|c|}
\hline \multirow[t]{2}{*}{ Variable } & \multirow[t]{2}{*}{$n$} & \multirow[t]{2}{*}{$\%$} & \multicolumn{2}{|c|}{$\mathrm{CD}_{4}$ cell count (cells $/ \mathrm{mm}^{3}$ ) } & \multicolumn{2}{|c|}{ HIV viral load (copies/mL) } \\
\hline & & & Median & IQR & Median & IQR \\
\hline Previous history of TB & 294 & 24.0 & 63 & $26-176$ & 97948 & $458-657750$ \\
\hline TB at current presentation & 244 & 19.9 & 109 & $37-296$ & 1740 & $0-240623$ \\
\hline First episode of TB & 216 & 88.5 & 59 & 25-156 & 106823 & 599-659 109 \\
\hline Recurrant episode of TB & 28 & 11.5 & 93 & $51-252$ & 962 & $15-422285$ \\
\hline Single-organ TB & 174 & 71.3 & 82 & $34-226$ & 25000 & $248-398515$ \\
\hline Disseminated miliary TB & 38 & 15.6 & 37 & $22-87$ & 361172 & 7050-1050 000 \\
\hline Disseminated non-miliary TB & 32 & 13.1 & 42 & 14-141 & 157532 & 2050-1 163090 \\
\hline Pulmonary $\mathrm{TB}^{\dagger} \dagger$ & 101 & 41.4 & 89 & 29-202 & 130000 & $450-710435$ \\
\hline Extrapulmonary TB: & 143 & 58.6 & 68 & 25-154 & 920468 & $288550-2334203$ \\
\hline Miliary TB & 38 & 15.6 & 37 & $22-87$ & 361172 & 7050-1050 000 \\
\hline Pleural TB & 31 & 12.7 & 139 & $56-313$ & 1510 & $0-69250$ \\
\hline Abdominal TB & 27 & 11.1 & 54 & 25-112 & 43100 & $710-475908$ \\
\hline Tuberculous meningitis (TBM) & 23 & 9.4 & 104 & $35-220$ & 141190 & $231-264500$ \\
\hline Tuberculous lymphadenitis & 10 & 4.1 & 21 & $7-75$ & 65200 & 1980-184000 \\
\hline Tuberculous pericarditis & 9 & 3.7 & 65 & $47-120$ & 3500 & 819-35 963 \\
\hline Tuberculoma & 4 & 1.6 & 150 & $26-269$ & 48373 & $15-1005044$ \\
\hline Urogenital TB & 3 & 1.2 & 76 & 39-183 & 210064 & $129459-805032$ \\
\hline Spinal TB & 2 & 0.8 & 525 & $512-537$ & 2097 & $1918-2275$ \\
\hline Tuberculous osteomyelitis & 1 & 0.4 & 15 & $15-15$ & 531001 & $531001-531001$ \\
\hline
\end{tabular}

Note: Probable cases of tuberculosis were also included as microbiological confirmation was not available for all cases.

$\mathrm{TB}$, tuberculosis; IQR, interquartile range.

$\dagger$, Only includes participants with isolated pulmonary tuberculosis. The total number of pulmonary tuberculosis cases will be 171 (70.1\%) if participants with both pulmonary and concurrent extrapulmonary tuberculosis are included. 
TABLE 4: The most frequent presenting diagnoses and corresponding median $\mathrm{CD}_{4}$ cell count and human immunodeficiency virus viral load amongst study participants.

\begin{tabular}{|c|c|c|c|c|c|c|}
\hline \multirow[t]{2}{*}{ Variable } & \multirow[t]{2}{*}{$n$} & \multirow[t]{2}{*}{$\%$} & \multicolumn{2}{|c|}{$\mathrm{CD}_{4}$ cell count (cells $/ \mathrm{mm}^{3}$ ) } & \multicolumn{2}{|c|}{ HIV viral load (copies/mL) } \\
\hline & & & Median & IQR & Median & IQR \\
\hline Central nervous system & 145 & 11.8 & 106 & $34-264$ & 13480 & 34-189970 \\
\hline Cryptococcal meningitis & 39 & 3.2 & 27 & $12-72$ & 130126 & $1062-300000$ \\
\hline Bacterial meningitis & 30 & 2.5 & 94 & $72-170$ & 36800 & $12040-224932$ \\
\hline Tuberculous meningitis & 23 & 1.9 & 104 & $35-220$ & 141190 & $231-264500$ \\
\hline Other & 53 & 4.3 & 272 & $114-480$ & 37 & 0-1895 \\
\hline Respiratory system & 533 & 43.5 & 71 & $13-72$ & 73300 & 2611-372 319 \\
\hline Bacterial pneumonia & 276 & 22.5 & 77 & $20-212$ & 75800 & $221-592500$ \\
\hline Pulmonary tuberculosis & 171 & 14.0 & 89 & 29-202 & 130000 & $450-710435$ \\
\hline Pneumocystis jirovecii pneumonia & 47 & 3.8 & 27 & $18-90$ & 429862 & $98057-551510$ \\
\hline Other & 39 & 3.2 & 275 & $124-406$ & 144 & $0-4670$ \\
\hline Cardiovascular system & 47 & 3.8 & 232 & $84-440$ & 680 & $0-20860$ \\
\hline Congestive cardiac failure & 18 & 1.5 & 225 & $114-351$ & 100 & $0-308000$ \\
\hline Other & 29 & 2.3 & 233 & $68-419$ & 1870 & $10-8855$ \\
\hline Chronic gastroenteritis & 30 & 2.5 & 50 & $11-177$ & 72334 & 389-496905 \\
\hline Abdominal tuberculosis & 27 & 3.0 & 54 & 25-112 & 43100 & $710-475908$ \\
\hline Tuberculous medication-induced hepatitis & 18 & 1.5 & 55 & $45-95$ & 20475 & $218-776000$ \\
\hline Other & 92 & 7.5 & 208 & $64-400$ & 45 & $0-118750$ \\
\hline Genitourinary system & 249 & 20.3 & 94 & $25-289$ & 1550 & $42-230426$ \\
\hline Acute kidney injury & 138 & 11.3 & 57 & 19-162 & 3636 & $40-400000$ \\
\hline Chronic kidney disease & 25 & 2.0 & 41 & $15-115$ & 5500 & $582-288500$ \\
\hline Acute chronic kidney disease & 22 & 1.8 & 67 & $20-220$ & 4050 & 43-175989 \\
\hline Urosepsis & 19 & 1.6 & 300 & $98-643$ & 108 & $31-6580$ \\
\hline Pelvic inflammatory disease & 14 & 1.1 & 298 & $196-421$ & 581 & $0-1295$ \\
\hline Other & 31 & 2.5 & 353 & $188-402$ & 498 & $13-48565$ \\
\hline Psychiatric & 78 & 6.4 & 320 & 110-476 & 37450 & $217-227750$ \\
\hline HIV-associated neurocognitive disorder & 15 & 1.2 & 138 & $74-298$ & 305480 & $81075-858500$ \\
\hline Parasuicide intentional overdose & 14 & 1.1 & 402 & $300-424$ & 10 & $0-3273$ \\
\hline Other & 24 & 1.9 & 397 & $111-553$ & 20844 & $228-296000$ \\
\hline Skin and soft tissue & 49 & 4.0 & 252 & $72-417$ & 39090 & $6318-933323$ \\
\hline Kaposi's sarcoma & 13 & 1.1 & 89 & $42-187$ & 917518 & $409512-3585400$ \\
\hline Cellulitis & 8 & 0.7 & 282 & $243-548$ & 2602 & $5-28070$ \\
\hline Herpes zoster & 6 & 0.5 & 122 & $18-142$ & 48000 & $8465-816000$ \\
\hline Other & 23 & 1.9 & 318 & $55-434$ & 6050 & $63-272358$ \\
\hline Haematological system & 58 & 4.7 & 125 & $49-244$ & 248 & 22-184000 \\
\hline Deep vein thrombosis & 20 & 1.6 & 152 & $97-247$ & 195 & $21-88600$ \\
\hline Lymphoma & 11 & 0.9 & 79 & $62-127$ & 86727 & $40218-262547$ \\
\hline Pulmonary embolism & 10 & 0.8 & 379 & $168-425$ & 155 & $60-734297$ \\
\hline Thrombotic thrombocytopenic purpura & 5 & 0.4 & 48 & 31-199 & 75500 & $102-624000$ \\
\hline Other & 12 & 1.0 & 42 & $10-152$ & 2260 & $220-213000$ \\
\hline
\end{tabular}

IQR, interquartile range; HIV, human immunodeficiency virus.

During the early days of the HIV epidemic and before the introduction of highly active antiretroviral therapy, hospital admission rates amongst PLWH were substantially higher, and predominantly because of opportunistic infections and other acquired immunodeficiency syndrome (AIDS)-defining illnesses. ${ }^{18}$ With the widespread introduction of effective ART, the life expectancy of PLWH is approaching that of the general population, and hospital admissions in these regions have begun to reflect age-related chronic illnesses or comorbidities rather than HIV-related acute illnesses. ${ }^{19}$

It is well established that the early initiation of ART and efforts to optimise ART adherence have been highly effective in curtailing the transmission of HIV and reducing HIV-associated morbidity and mortality. ${ }^{20,21,22,23}$ Hence, it is of concern that despite the free availability of
ART to all South African PLWH, ${ }^{11}$ over two-thirds of study participants presented with opportunistic infections and other HIV-related acute illnesses. The high percentage of participants with $\mathrm{CD}_{4}$ cell counts $<100 \mathrm{cell} / \mathrm{mm}^{3}(47.6 \%)$, HIV VL > 1000 copies $/ \mathrm{mL}(59.0 \%)$ and the large number of participants newly diagnosed with HIV $(17.3 \%)$, or naïve to ART (24.9\%) and those non-adherent to ART (32.2\%) highlight the need for an urgent public health response and the implementation of innovative strategies to improve current HIV awareness and educational programmes, as well as to increase the rates of ART initiation, ART adherence and retention in care.

A previous systematic review and meta-analysis that included 313006 pooled adult patients from 99 studies conducted in 50 countries, with studies being mostly 
TABLE 5: Quick sequential organ failure assessment and national early warning score illness severity scores, patient disposition from the emergency department, length of hospital stay and in-hospital mortality amongst study participants.

\begin{tabular}{lll}
\hline Variable & $\boldsymbol{n}$ & $\mathbf{\%}$ \\
\hline qSOFA score & & \\
Low score (0-1 point) & 921 & 82.5 \\
High score (2-3 points) & 196 & 17.5 \\
NEWS-2 score & & \\
Low score (0-4 points) & 449 & 40.2 \\
Medium score† (5-6 points) & 171 & 15.4 \\
High score ( 7 points) & 496 & 44.4 \\
Disposition from the emergency department & & \\
General ward admission & 813 & 66.5 \\
ICU admission & 205 & 16.7 \\
Discharged home from ED & 206 & 16.8 \\
Length of hospital stay & & \\
$<7$ days & 830 & 67.8 \\
$\geq 7$ days & 394 & 32.2 \\
In-hospital mortality & 166 & 13.6 \\
\hline
\end{tabular}

ED, emergency department; qSOFA, quick sequential organ failure assessment; NEWS, National Early Warning Score; ICU, intensive care unit.

$\dagger$. Includes patients with an overall low score but a score of 3 in any individual parameter.

conducted between 2007 and 2015 and reflecting a time when access to ART had become more widespread than before this period, reported that HIV and AIDS-related illnesses (46\%) and bacterial infections (31\%) were the most common reasons for hospital admission in all geographical regions. Acquired immunodeficiency syndrome-related illnesses were mostly non-bacterial opportunistic infections. ${ }^{24}$ Comparatively, in this study, a slightly lower proportion $(68.4 \%)$ of participants presented with an infectious aetiology (bacterial and non-bacterial), fewer participants were diagnosed with HIV at presentation $(17.3 \%$ vs. $30 \%)$, more were on ART $(75.1 \%$ vs. $43 \%)$, the median length of hospital stay was shorter (4.3 days vs. 9 days) and in-hospital mortality was lower $(13.6 \%$ vs. $20 \%)$. Despite this, the median $\mathrm{CD}_{4}$ cell count was lower (112 cells $/ \mathrm{mm}^{3}$ vs. 168 cells $/ \mathrm{mm}^{3}$ ) in this study. Additionally, there was a higher percentage of participants in this study with bacterial pneumonia $(22.5 \%$ vs. $15 \%)$ and TB (19.9\% vs. $18 \%)$, whilst a lower percentage of patients were admitted with Pneumocystis jirovecii pneumonia $(3.8 \%$ vs. $8 \%)$ and gastroenteritis $(7.1 \%$ vs. $9 \%)$. Also, there were more cases of ЕРTВ (58.6\%) than isolated PTB (41.4\%) in this study, in contrast to the pooled studies in which $67 \%$ presented with PTB. As the meta-analysis represented a wider demographic pool of patients, this may be a likely reason for the difference between findings of that study and this study.

A separate systematic review and meta-analysis consisting of 56 pooled studies conducted in SSA, which investigated trends in $\mathrm{CD}_{4}$ cell count at presentation to a medical facility between 2002 and 2013, found that the mean estimated $C_{4}$ cell count was 251 cells $/ \mathrm{mm}^{3}$ in 2002 and 309 cells $/ \mathrm{mm}^{3}$ in 2012, with no significant annual increase over the entire period. However, of the 13 studies conducted in SA, a significant increase in the $\mathrm{CD}_{4}$ cell count of 39.9 cells per annum $(p=0.02)$ was noted from 2002 to 2013. The overall mean $\mathrm{CD}_{4}$ cell count of the 13 studies conducted in SA was 257 cell $/ \mathrm{mm}^{3}, 25$ whereas in the current study this was lower $\left(209 \mathrm{cell} / \mathrm{mm}^{3}\right)$. This study is unique in that it was conducted at a tertiary-level facility, which excluded patients with low acuity conditions as they were triaged to lower-level care facilities. However, the aforementioned meta-analysis included studies conducted at 'prevention of mother to child transmission (PMTCT) clinics' and other lower level of care centres, which may explain the lower mean $\mathrm{CD}_{4}$ cell count observed in this study.

With regard to other findings of this study, anaemia in HIVpositive patients has been shown to be an independent predictor of clinical response, with a study showing that severe anaemia at baseline was associated with 13 times higher risk of death within the first year of ART initiation. ${ }^{26}$ Another study showed that an increasing severity of anaemia was associated with higher rates of TB and mortality, and was superior to the $\mathrm{CD}_{4}$ cell count as a predictive marker in patients on ART.27

Acute kidney injury was reported in $11.3 \%$ of study participants. Other studies reported rates of acute renal dysfunction of $2.9 \%-18 \%,{ }^{28,29,30}$ with the incidence being still high in the post-ART era. ${ }^{28}$ Similar to findings of this study, acute renal dysfunction has been reported more commonly in patients with a low $\mathrm{CD}_{4}$ cell count and high HIV VL. ${ }^{29}$

With regard to other significant study findings, the relatively high number of participants with an elevated CRP (84.5\%), hypoalbuminemia $(60.8 \%)$, hyperlactatemia (42\%), thrombocytopaenia (19.9\%) and a high qSOFA score $(17.5 \%)$ is in line with the large number of participants presenting with severe illnesses. Previous studies have shown that elevated CRP, ${ }^{31}$ albuminemia, ${ }^{32}$ hyperlactatemia, ${ }^{33}$ thrombocytopaenia ${ }^{34}$ and higher qSOFA scores ${ }^{35,36}$ were predictors of mortality and poor outcomes in HIV-positive individuals.

\section{Limitations}

Limitations of this study are that this was a single-centre study, and that data were collected over a relatively short duration of 15 months. Also, with regard to the median $\mathrm{CD}_{4}$ cell count and HIV VL values described in Tables 3 and 4, we did not account for differences between participants who were on ART and those who were not on ART or were ART non-adherent. Furthermore, as the study was conducted at a tertiary-level academic hospital and excluded patients with less severe presenting illnesses, our cumulative findings are likely to be an overestimate and not be fully reflective of the wider HIV-positive population residing within the drainage area of the hospital. A further limitation is the lack of data on chronic comorbid diseases, such as hypertension and diabetes, and the absence of follow-up outcomes post-discharge.

\section{Conclusion}

Despite the passage of more than 30 years of the HIV pandemic in Africa, PLWH are still at risk of serious morbidity and inappropriate mortality. In order to achieve 
the target of ending HIV by 2030 in SA, a more urgent public health response is required. This must include more innovative strategies to improve HIV awareness, new thoughts with regard to prevention, upgrading of ART services and dedication to the retention of all PLWH in care.

\section{Acknowledgements}

The authors would like to thank the staff at the Charlotte Maxeke Johannesburg Academic Hospital for their assistance with identifying potential study participants.

\section{Competing interests}

The authors declare that they have no financial or personal relationships that may have inappropriately influenced them in writing this article.

\section{Authors' contributions}

A.E.L. was the primary author and was responsible for the study design, data collection, data analysis, manuscript write-up, revision and approval of the final manuscript. W.D.F.V., G.A.R. and F.P. assisted with the study design, interpretation of results, revision of the manuscript and approval of the final manuscript.

\section{Funding information}

This research was self-funded and did not receive any specific grant from funding agencies in the public, commercial or not-for-profit sectors.

\section{Data availability statement}

Data pertaining to this study are available from the corresponding author, A.E.L., upon request.

\section{Disclaimer}

The views and opinions expressed in this article are those of the authors and do not necessarily reflect the official policy or position of the institution or funder.

\section{References}

1. UNAIDS. UNAIDS data 2020 [homepage on the Internet]. 2020 [cited 2020 Aug 21]. Availabele from: https://www.unaids.org/sites/default/files/media_ asset/2020_aids-data-book_en.pd

2. List of countries by HIV/AIDS adult prevalence rate [homeapege on the Internet] 2020 [cited 2020 Sep 27]. Available from: https://en.wikipedia.org/wiki/List of countries_by_HIV/AIDS_adult_prevalence_rate

3. Zhu H, Napravnik S, Eron JJ, et al. Decreasing excess mortality of HIV-infected patients initiating antiretroviral therapy. J Acquir Immune Defic Syndr. 2013;63(5):e150-e157. https://doi.org/10.1097/QAl.0b013e3182948d82

4. Cornell M, Grimsrud A, Fairall L, et al. Temporal changes in programme outcomes among adult patients initiating antiretroviral therapy across South Africa, 2002-2007. AIDS. 2010;24(14):2263-2270. https://doi.org/10.1097/QAD.0b013e32833d45c5

5. Jaggy C, Von Overbeck J, Ledergerber B, et al. Mortality in the Swiss HIV cohort study (SHCS) and the Swiss general population. Lancet. 2003;362(9387):877-878. https://doi.org/10.1016/S0140-6736(03)14307-3

6. UNAIDS. Global factsheets 2019 [homepage on the Internet]. 2020 [cited 2020 Sep 28]. Available from: https://aidsinfo.unaids.org/

7. Mitiku H, Teklemariam Z, Weldegebreal F. Magnitude of opportunistic infections and associated factors in HIV-infected adults on antiretroviral therapy in eastern Ethiopia. HIV/AIDS - Res Palliat Care. 2015;2015:137-144. https://doi.org/10.2147/HIV.S79545
8. Matoga MM, Rosenberg NE, Stanley CC, et al. Inpatient mortality rates during an era of increased access to HIV testing and ART: A prospective observational study in Lilongwe, Malawi. PLoS One. 2018;13(2):e0191944. https://doi.org/10.1371/ journal.pone.0191944

9. Bangsberg DR, Perry S, Charlebois ED, et al. Non-adherence to highly active antiretroviral therapy predicts progression to AIDS. AIDS. 2001;15(9):1181-1183. https://doi.org/10.1097/00002030-200106150-00015

10. Budgell EP, Maskew M, Long L, Sanne I, Fox MP. Brief report: Does most mortality in patients on ART occur in care or after lost to follow-up? Evidence from the Themba Lethu Clinic, South Africa. J Acquir Immune Defic Syndr. 2015; 70(3):323-328. https://doi.org/10.1097/QAI.0000000000000755

11. Cullinan K. ARVs now for anyone with HIV - Motsoaledi 2016 [homepage on the Internet]. [cited 2020 Aug 08]. Available from: https://www.health24.com/ medical/hiv-aids/management-of-hiv-aids/arvs-now-for-anyone-with-hiv-saysminister-20160510

12. UNAIDS. UNAIDS data 2019 [homepage on the Internet]. 2019 [cited 2020 Sep 28]. Available from: https://rstesa.unaids.org/documents/publications/77-2019unaids-data-en/

13. UNAIDS. 90-90-90 An ambitious treatment target to help end the AIDS epidemic [homepage on the Internet]. 2014 [cited 2017 May 22]. Available from: http:// www.unaids.org/sites/default/files/media_asset/90-90-90_en.pdf

14. Bruijns SR, Wallis LA, Burch VC. A prospective evaluation of the Cape triage score in the emergency department of an Urban Public Hospital in South Africa. Emerg Med J. 2008;25(7):398-402. https://doi.org/10.1136/emj.2007.051177

15. Chesney MA, Ickovics JR, Chambers DB, B, et al. Self-reported adherence to antiretroviral medications among participants in HIV clinical trials: The AACTG adherence instruments. AIDS Care. 2000;12(3):255-266. https://doi. org $/ 10.1080 / 09540120050042891$

16. qSOFA. quick sepsis related organ failure assessment [homepage on the Internet] 2016 [cited 2020 Sep 13]. Available from: https://qsofa.org/

17. National Early Warning Score (NEWS) 2 [homepage on the Internet]. 2017 [cited 2020 Sep 12]. Available from: https://www.rcplondon.ac.uk/projects/outputs/ national-early-warning-score-news-2

18. Meijide H, Mena Á, Rodríguez-Osorio I, et al. Trends in hospital admissions, re-admissions, and in-hospital mortality among HIV-infected patients between 1993 and 2013: Impact of hepatitis C co-infection. Enferm Infecc Microbiol Clin. 2017;35(1):20-26. https://doi.org/10.1016/j.eimc.2016.07.012

19. Yang H-Y, Beymer MR, Suen S-C. Chronic disease onset among people living with HIV and AIDS in a large private insurance claims dataset. Sci Rep. 2019:9:18514. https://doi.org/10.1038/s41598-019-54969-3

20. Gakhar H, Kamali A, Holodniy M. Health-related quality of life assessment after antiretroviral therapy: A review of the literature. Drugs. 2013;73:651-672. https://doi.org/10.1007/s40265-013-0040-4

21. Albert J, Berglund T, Gisslén M, et al. Risk of HIV transmission from patients on antiretroviral therapy: A position statement from the Public Health Agency of Sweden and the Swedish Reference Group for Antiviral Therapy. Scand J Infect Dis. 2014;46(10):673-677. https://doi.org/10.3109/00365548.2014.92 6565

22. Tapson VF. Acute pulmonary embolism. N Engl J Med. 2008;358:1037-1052. https://doi.org/10.1056/NEJMra072753

23. Mannheimer S, Friedland G, Matts J, Child C, Chesney M. The consistency of adherence to antiretroviral therapy predicts biologic outcomes for human immunodeficiency virus-infected persons in clinical trials. Clin Infect Dis. 2002;34(8):1115-1121. https://doi.org/10.1086/339074

24. Ford N, Shubber Z, Meintjes G, et al. Causes of hospital admission among people living with HIV worldwide: A systematic review and meta-analysis Lancet HIV. 2015;2(10):e438-e444. https://doi.org/10.1016/S2352-3018(15) 00137-X

25. Siedner MJ, Ng CK, Bassett IV, Katz IT, Bangsberg DR, Tsai AC. Trends in CD4 count at presentation to care and treatment initiation in sub-Saharan Africa, 2002-2013: cid/ciu1137

26. Yesuf $T$, Muhie $O A$, Shibru $H$. Prevalence and predictors of anemia among adult HIV infected patients at the University of Gondar Hospital, Northwest Ethiopia. HIV/AIDS - Res Palliat Care. 2019;11:211-217. https://doi.org/10.2147/HIV. HIV/AIDS
S209446

27. Kerkhoff AD, Wood R, Cobelens FG, Gupta-Wright A, Bekker L-G, Lawn SD. The predictive value of current haemoglobin levels for incident tuberculosis and/or mortality during long-term antiretroviral therapy in South Africa: A cohort study. BMC Med. 2015;13:70. https://doi.org/10.1186/s12916-015-0320-9

28. Wyatt CM, Arons RR, Klotman PE, Klotman ME. Acute renal failure in hospitalized patients with HIV: Risk factors and impact on in-hospital mortality. AIDS. 2006;20(4):561-565. https://doi.org/10.1097/01.aids.0000210610.52836.07

29. Franceschini N, Napravnik S, Eron JJ, Szczech LA, Finn WF. Incidence and etiology of acute renal failure among ambulatory HIV-infected patients. Kidney Int 2005;67(4):1526-1531. https://doi.org/10.1111/j.1523-1755.2005.00232.x

30. Lopes JA, Melo MJ, Viegas A, et al. Acute kidney injury in hospitalized HIV-infected patients: A cohort analysis. Nephrol Dial Transplant. 2011;26(12):3888-3894. https://doi.org/10.1093/ndt/gfr192

31. Lau B. C-reactive protein is a marker for human immunodeficiency virus disease progression. Arch Intern Med. 2006;166(1):64-70. https://doi.org/10.1001/ archinte.166.1.64

32. Sudfeld $C R$, Isanaka $S$, Aboud $S$, et al. Association of serum albumin concentration with mortality, morbidity, CD4 T-cell reconstitution among tanzanians initiating antiretroviral therapy. J Infect Dis. 2013;207(9):1370-1378. https://doi.org/10.1093/ infdis/jit027 
33. Tantisiriwat W, Tebas P, Polish LB, Casabar E, Powderly WG, Fichtenbaum CJ. Elevated lactate levels in hospitalized persons with HIV infection. AIDS Res Hum Retroviruses. 2001;17(3):195-201. https://doi.org/10.1089/088922201750063106

34. Johannessen A, Naman E, Ngowi BJ, et al. Predictors of mortality in HIV-infected patients starting antiretroviral therapy in a rural hospital in Tanzania. BMC Infect Dis. 2008:8:52. https://doi.org/10.1186/1471-2334-8-52
35. Maphula RW, Laher AE, Richards GA. Patterns of presentation and survival of 2020;21(5):334-341. https://doi.org/10.1111/hiv.12834

36. Aluisio AR, Garbern S, Wiskel T, et al. Mortality outcomes based on ED qSOFA score and HIV status in a ding 2018;36(11):2010-2019. https://doi.org/10.1016/j.ajem.2018.03.014. 